NBER WORKING PAPER SERIES

\title{
TIME TO EAT: \\ HOUSEHOLD PRODUCTION \\ UNDER INCREASING INCOME INEQUALITY
}

\author{
Daniel S. Hamermesh \\ Working Paper 12002 \\ http://www.nber.org/papers/w12002
NATIONAL BUREAU OF ECONOMIC RESEARCH
1050 Massachusetts Avenue
Cambridge, MA 02138
January 2006

Edward Everett Hale Centennial Professor of Economics, University of Texas at Austin, research associate, NBER, and program director, IZA. Research support was provided by the U.S. Department of Agriculture under Cooperative Aggreement 43-3AEM-4-80125. I am indebted to Moshe Buchinsky, Anne Golla, Karen Hamrick, Susan Himmelweit, Dan Slesnick, Hayden Stewart, Yoram Weiss and particiants at several conferences and seminars for helpful suggestions, and to Rick Evans and Mark Pocock for research assistance. The views expressed herein are those of the author(s) and do not necessarily reflect the views of the National Bureau of Economic Research.

(C2006 by Daniel S. Hamermesh. All rights reserved. Short sections of text, not to exceed two paragraphs, may be quoted without explicit permission provided that full credit, including $\odot$ notice, is given to the source. 
Time to Eat: Household Production Under Increasing Income Inequality

Daniel S. Hamermesh

NBER Working Paper No. 12002

January 2006

JEL No. J22, Q11

\begin{abstract}
$\underline{\text { ABSTRACT }}$
Eating requires the food materials that make up meals and also time devoted to buying food, preparing meals and eating them, and cleaning up afterwards. Using time-diary and expenditure data for the U.S. for 1985 and 2003, I examine how income and time prices affect time and goods input into this household-produced commodity. Focusing on these two years, between which income and earnings inequality increased, allows examining how household production is affected by changing economic opportunities. The results demonstrate that both inputs into eating increase with income, and that higher time prices at a given level of income reduce time inputs. Over this period the goods intensity of producting this commodity increased, especially at the lower oart of the income distribution, and the eaverage time input dropped substantially. The results are consistent with goods-time substitution in eating being relatively difficult and with substitution becoming relatively more difficult as production expands. This is confirmed by direct estimates using matched time-use and food spending data on the same households for 2003 and 2004 . The findings imply that projecting food expenditures alone overestimates the amount spent on food in a growing economy.
\end{abstract}

Daniel S. Hamermesh

Department of Economics

University of Texas

Austin, TX 78712-1173

and NBER

hamermes@eco.utexas.edu 


\section{Introduction}

There are two activities that every person must do to survive: Eat and sleep. While the latter is amenable to economic analysis (see Biddle and Hamermesh, 1990), with the exception of an infrequent purchase of bedding and mattresses the production of sleep is a decision solely about time use. Not so for eating: Generating meals requires decisions about money expenditures on the capital required to engage in this activity and on the non-durable good food itself, as well as about the time spent in obtaining food, preparing it, consuming it and cleaning up the detritus from the meal. How people combine expenditures on the goods and time that make up the production of the commodity "eating" is the major focus of this study, and I will present evidence on these combinations and their changes over the past two decades in the United States.

Essentially no attention has been paid to analyzing how the production of eating takes place in the household. The only relevant literature includes Gronau and Hamermesh (2006), who provide measures of the relative goods intensity of "eating" (and other commodities) in the U.S. and Israel, and Lecocq (2001), who examines food spending and (only) meal preparation time (from recall data) in France. Crossley and $\mathrm{Lu}$ (2004) study the details of food spending and meal preparation time using two separate surveys, while Aguiar and Hurst (2005) examine time and goods inputs into eating at a point in time using data on older Americans from two separate surveys, one of expenditures on goods, the other a time-diary study. Vernon (2004) has data on food spending and (recall data) on time use for samples of Russian households in the 1990s. No study tries to combine the spending and time use measures to infer how the goods-intensity of household production varies with full income.

Because decisions about how to generate "eating" depend on choices about how time is spent in the activity, and because the value of time differs across individuals (and for the same person at different times of the day, week, year and lifetime), they are inherently economic. Thus even though we all may face the same price of the goods that are inputs into "eating," we will choose different combinations of goods and time to generate the same amount of "eating" (Becker, 1965) even when our household incomes are equal. A second purpose here will thus be to analyze how household members' choices of the amounts of time and goods to devote to eating are affected by differences in economic incentives. 
Gronau's (1980) pioneering work considered inter alia the role of income in affecting household production. Given the potential importance of income effects, it seems sensible to examine the dynamics of this relationship, since arguably the most important change in the American economy (and to a lesser extent in many other industrialized economies too) in the last quarter century has been the rise in inequality in earnings and incomes (see e.g., Gottschalk and Smeeding, 2000). Among its many potential impacts rising income inequality, and the relative changes in time prices that constitute the source of much of the increased inequality, may also have altered the incentives for generating commodities in the household, including "eating," that face people at different points of the distributions of earnings and incomes. The extent of changes resulting from these changed incentives, and therefore the distributional impacts of rising inequality on how Americans generate "eating," is the third central focus of this study. ${ }^{1}$

In the next Section I provide a brief motivation for the analysis. Section III discusses the large variety of data sets that are used in this study and outlines ways to overcome a number of complex estimation problems that are thrown up by difficulties with the available data, including the likely endogeneity of variations in wages and incomes. Section IV presents the empirical results that shed light on the first two foci of the study. It also analyzes changes in the inputs into eating over the two decades from the mid-1980s to the mid-2000s and what they imply about the household production function for eating.

\section{Theoretical Motivation}

The discussion of household production for eating is fairly standard and stems directly from Becker (1965). The typical household chooses to supply its members' labor to the market, and to use its remaining time in a variety of activities that it combines with the income generated by its members' labor market time and any non-labor income it may receive. Among these activities are those related to eating; and among the goods purchased are food and the capital necessary to convert that food into meals. Given the household's preferences, it will thus determine its utility-maximizing production of the commodity eating. It will generate demands for time and goods inputs into eating as:

${ }^{1}$ Gottschalk and Mayer (2002) examine the general question of how changing household time use affects inferences about changing inequality by valuing several (recall) measures of time spent in household activities and adding the total to household income. 
and

$$
\mathrm{X}=\mathrm{X}\left(\mathrm{W}_{\mathrm{M}}, \mathrm{W}_{\mathrm{F}}, \mathrm{I} ; \mathrm{Z}\right) \text {, }
$$

where $\mathrm{T}$ is its time input into eating, $\mathrm{X}$ its dollar expenditures on food, $\mathrm{W}_{\mathrm{M}}$ and $\mathrm{W}_{\mathrm{F}}$ are the husband's and wife's value of time, $\mathrm{I}$ is unearned income, and $\mathrm{Z}$ is a vector of demographic characteristics that might shift the demand functions for time and goods. We have written the model for a two-adult household, since the data require us to use such households in the empirical analyses; but a similar, simpler model could be written down for a single-adult household.

The economically interesting questions have to do with the expansion paths of the demand for inputs into eating and their changes as incomes and the prices of time change. The effects of exogenous changes in the economic variables on the choices of $\mathrm{T}$ and $\mathrm{X}$ are fairly standard: 1) Because the total endowment of time is fixed, in (1a) a higher price of time may or may not cause a shift away from using time in producing eating. The outcome depends on the relative time intensity of eating compared to other commodities and on the relative substitutability of goods and time in eating. There is some evidence (Gronau and Hamermesh, 2006) that eating is relatively goods-intensive. If so, as the price of time increases people would expand their production of eating, although they would surely attempt to do so in an increasingly goods-intensive way. As their non-labor income increases, they will expand their production of eating, perhaps using more time (again, depending on the relatively substitutability of goods and time in producing this commodity compared to others). In the end the directions of the effects of $\mathrm{W}_{\mathrm{M}}, \mathrm{W}_{\mathrm{F}}$ and $\mathrm{I}$ on $\mathrm{T}$ depend on a variety of characteristics of the production of eating and of eating relative to other household-produced commodities; but we do expect that I will have a more positive effect on $\mathrm{T}$ than will $\mathrm{W}_{\mathrm{M}}$ or $\mathrm{W}_{\mathrm{F}}$. 2) For most commodities, including probably eating, increases in income, whether due to a higher price of time (as reflected in higher wages per hour of market work) or higher non-labor income will increase total goods expenditures. We thus expect each of the three economic variables in (1b) to have positive effects on $\mathrm{X}$. 


\section{Data and Measurement Issues}

Sadly there are no single data sets that combine information on households' goods expenditures and time actually spent (as recorded in time diaries) by all household members in the production of eating. One data set does make it possible to combine such information for one household member's time use and the household's food spending, and I return to that later. Both for the U.S. and for other countries, however, we do have detailed consumer expenditure surveys covering large samples of households. We also have detailed time budgets that typically cover smaller samples. In this study we use the 1985 Time Use Survey (TUS85) for the United States, a relatively small privately conducted survey that obtained one day's time diaries from single individuals and from both spouses in a married household and collected some demographic information on both spouses and other household members (Robinson and Godbey, 1999). The 1985 Consumer Expenditure Survey (CES85) contains detailed categories of spending as well as a set of demographic variables that are similar in scope to those included in the TUS85.

Because I am interested in comparing how rising wage and income inequality affects the production of eating in the household, I estimate the same models on data from 2003, when income inequality was greater than in $1985 .^{2}$ The year 2003 is chosen because it is the first year in which the Bureau of Labor Statistics collected data in the American Time Use Survey (ATUS03), which offers for that year a sample of one-day time diaries from nearly 21,000 individuals who had recently been Current Population Survey (CPS) respondents (see Horrigan and Herz, 2005). I analyze these data along with information on goods expenditures from households in the 2003 Consumer Expenditure Survey (CES03). Particularly in the TUS85 there are too few single individuals to allow a useful analysis to be conducted, so I restrict the study to married individuals with spouse present. I further restrict the analyses to married persons ages 18-64, as I wish to avoid issues related to the well-known unexpectedly large drop that occurs around the normal retirement age (Hamermesh, 1984).

One of the reasons why there have been so few efforts to estimate household production functions may be because of the necessity of classifying activities and expenditures into commodities. Any

\footnotetext{
${ }^{2}$ In 1985 the Gini coefficient on household incomes in the U.S. was 0.425 , and the 80/20 ratio was 4.25 . In 2003 the same statistics were 0.464 and 4.83 .
} 
classification is necessarily arbitrary; and the difficulty is exacerbated if we wish to compare household production across time, since the list of activities included in time diaries I use changed between the two surveys. I thus arbitrarily classify certain time and expenditure categories as representing inputs into eating.

The exact classifications used in extracting information from the four samples, the TUS85, the ATUS03, and the CES85 and CES03, are listed in Appendix Table 1. For the time-use surveys I include the exact codes identifying the categories treated as constituting food activities. The goal in classifying activities is to include as time inputs into eating those activities that are described as eating at home and away from home (including at work), meal preparation and clean-up, and grocery shopping and travel related to grocery shopping. I thus try to include all time spent at meals no matter where they are taken or what the purpose. Nonetheless, some people may classify an activity such as drinking at a bar as part of their leisure activities, so that it may not be and perhaps should not be included as a time input into this commodity. Because it is not separately classified in both the TUS85 and ATUS03, I do not include travel to eat away from home, in order to maintain comparability across the two years. Because the TUS85 collected no information on secondary activities (things done simultaneously with the activity that is reported in the survey), and the ATUS03 only reported secondary childcare activity, there is nothing we can do about the possibility that food preparation or clean-up might have been done as an activity secondary to something else and might thus have been under-reported. ${ }^{3}$

Expenditures on food and alcohol (the latter counted only as half) are the main components of goods inputs into eating; but I also include spending on small appliances (presumably for the kitchen) and arbitrarily treat one-third of expenditures on major appliances as inputs into eating (on the assumption that some of these items represent kitchen appliances such as refrigerators, stoves and dishwashers). While these classifications are arbitrary, they are identical for all households. Moreover, since in the

\footnotetext{
${ }^{3}$ Evidence from the 1991/92 German Zeitbudgeterhebung, which includes reports of secondary activities, suggests that this is not a problem. Only 5 percent of all eating time was reported as secondary, far less than the average incidence of secondary time reported. Cleaning, cooking and shopping (for all items, not just groceries) accounted for only 9 percent of all secondary activities, less than their representation among primary activities. When people report eating, shopping, food preparation or clean-up, it is the primary activity, with television-watching, radiolistening or childcare often being secondary to them. The small extent of secondary time spent in the commodity "eating" suggests that our necessary neglect of it here is unimportant.
} 
empirical analysis I shall essentially be differencing patterns of household production across income levels and across years, so long as the full-income elasticity of demand for the various inputs is constant across the years much of any misclassifications will be differenced out. Finally, I replicated the analyses of the determinants of expenditures using only the narrowest CES definition of expenditures on eating, namely spending on food alone, and found no qualitative differences from the results presented here.

The TUS85 has only extremely broad classifications of household income and spouses' hourly earnings. While the ATUS03 provides good information on earnings, good information on incomes is available for the fewer than one-third of ATUS03 respondents who were also included in the March 2003 CPS Income Supplement. Even if the data sets had better and more extensive measures of these economic variables, however, using them would introduce biases into estimates of household production: An individual's earnings, and his/her household income, are generated by the wage rate. But the latter in turn depends on the time that the individual chooses to devote to market work (Biddle and Zarkin, 1989); and that choice in turn is determined simultaneously with choices of time inputs into producing different commodities, including eating, in the household. In order to obtain unbiased estimates of the household production function we must somehow find instrumental variables for the wage and income measures that are central to the analysis.

Write the estimating equations for time and goods expenditures into eating as:

(2a) $\mathrm{T}_{\mathrm{it}}=\alpha \mathrm{Y}_{\mathrm{it}}+\varepsilon_{\mathrm{it}}$,

and

(2b) $\mathrm{X}_{\mathrm{it}}=\beta \mathrm{Y}_{\mathrm{it}}+v_{\mathrm{it}}, \mathrm{t}=1985,2003$,

where $\mathrm{i}$ is an observation (couple), $\mathrm{t}$ is a year (1985 or 2003) and $\mathrm{Y}$ denotes a vector of economic variables consisting of the spouses' wage rates and household income in (2a) and perhaps the same variables or a subset of them in (2b). There are no satisfactory instruments for the variables in the vector $\mathrm{Y}$ in these data sets. The data sets do, however, provide information on a set of variables $\mathrm{Z}$ that are reasonably viewed as determinants of the $\mathrm{Y}$ and as exogenous to goods and time use by adults. Moreover, information on both the $\mathrm{Z}$ and the $\mathrm{Y}$ variables is available from other sets of data that also 
sample randomly from the U.S. population at the same times as the 1985 and 2003 time-use and expenditure surveys that we use.

I use the Panel Study of Income Dynamics for 1986 (PSID86), which has information on 1985 household net (after federal taxes) income, Y1, to estimate:

(3a) $\quad \mathrm{Y} 1_{\text {it }}=\gamma Z 1_{\text {it }}+\xi_{\text {it }}$,

where $\mathrm{Z} 1$ is a vector of exogenous variables. I then take the estimates of the vector of parameters $\gamma^{*}$ to create instruments $\mathrm{Y}^{*}$ using the $\mathrm{Z} 1_{\mathrm{it}}$ in the TUS85 and the CES85. Similarly, I use the Panel Study of Income Dynamics for 2003 (PSID03) to create instruments for net income using the $\mathrm{Z1}_{\mathrm{it}}$ in the ATUS03 and CES03. ${ }^{4}$ Included in the vector $\mathrm{Z} 1$ are a vector of indicators of the educational attainment of each spouse, quadratics in each spouse's age, and the number of children under age 6 and ages 6-17.

For each spouse's wage rate I estimate:

$$
\mathrm{W}_{\mathrm{jit}}=\delta \mathrm{Z} 2_{\mathrm{jit}}+\zeta_{\mathrm{jit}}, \mathrm{t}=1985,2003 \text {, }
$$

where $\mathrm{W}_{\mathrm{j}}(\mathrm{j}=\mathrm{M}, \mathrm{F})$ is the usual weekly earnings of workers in the Merged Outgoing Rotation Groups of the 1985 and 2003 CPS. For each married person age 18-64 (the same age group that we use in the main data sets), the wage is predicted from a vector Z2 describing their education, reported usual weekly hours and a quadratic in their age. In describing the earnings of married women we account for Gronau's (1974) wage selectivity into the labor force by using Heckman's (1979) two-step method. The imputations of both net income and hourly earnings using this two-sample instrumental variable approach (Angrist and Krueger, 1992) circumvent both the potential endogeneity of these variables in the time use and CES data sets and the absence of good information on earnings and incomes in the TUS85 and on incomes in the ATUS03.

The absence of information on both time use and goods expenditures in the same sample presents difficulties for generating estimates of how these are combined to create the commodity eating. We simply do not observe time and goods expenditures on eating in any particular household. One solution would be to aggregate the measures in each sample into age-education cell averages. The difficulty with

\footnotetext{
${ }^{4}$ Only information on gross income is available in the PSID03. To derive analog to the data for 1985 I subtract the standard deduction and personal exemptions from gross income and apply the 2002 tax tables.
} 
this solution, at least for 1985 because the TUS85 sample is quite small, is that the cells would either be very few in number or very sparsely populated. A better solution is to recognize that both the time-use survey and the CES for each year sample from the same underlying population. Similarly, the instruments for income and hourly earnings are also based on the same populations. Each sample's imputed values of the variables in the vector $\mathrm{Y}$ thus represent unbiased estimates of the underlying distributions of the variables in the vector. We can thus use them as if they were measuring income and time prices in the household to which they are imputed and treat the estimates of equations (2) as reflecting the demands for goods and time inputs into eating. ${ }^{5}$ To maintain comparability across the two years, and to allow concentrating on the impacts of changing inequality, we transform the instrumental estimates into percentile points (so that, for examples, in the TUS85 the household with the median imputed net income would be assigned a value of 50 for imputed net income, the wife in the household in the CES03 with an imputed hourly earnings at the $75^{\text {th }}$ percentile of wives' earnings would be assigned a value of 75 for this variable, etc.). ${ }^{6}$

The central estimates are of the equations:

(2a') $\ln (\mathrm{T})_{\mathrm{it}}=\alpha^{\prime} \mathrm{YP}_{\mathrm{it}}+\varepsilon_{\mathrm{it}}$,

and

(2b') $\quad \ln (\mathrm{X})_{\mathrm{it}}=\beta^{\prime} \mathrm{YP}_{\mathrm{it}}+v_{\mathrm{it}}, \mathrm{t}=1985,2003$

where the YP are the percentile points of the distributions of imputed net income and hourly earnings measures. $^{7}$ The estimated $\alpha^{\prime}$ and $\beta^{\prime}$ measure the percentage impacts of one-percentile increases in household incomes or hourly earnings (time prices) on the representative household's total time and goods inputs respectively into the production of eating.

A final difficulty is that, while we have time diaries for both spouses in the TUS85, the ATUS03 only collected a time diary for one household member. For 2003 we thus cannot obtain T simply by

\footnotetext{
${ }^{5}$ These input-demand equations leave out the prices of goods under the assumption that they are identical for all individuals at a point in time.

${ }^{6}$ Appendix Table 2 presents a concordance of all the data sets used in this study.

${ }^{7}$ The equations were also estimated with linear forms of the dependent variables with little qualitative difference in the results.
} 
summing up spouses' time spent on food. Because the ATUS03 households have been in the CPS, however, we do have information on all the variables Z characterizing ATUS03 respondents and their spouses that we used to create the instruments for the variables in the vector Y. I thus generate predictions of food time for husbands and wives on whom the ATUS provides time diaries, with the fitted values based on each spouse's age, education, reported weekly hours of market work, race, ethnicity, and age distribution of children. I then use the same equations to generate fitted values for husbands for whom no diary is available, and use nearest-neighbor matching on the fitted values to impute the missing time spent on food for those husbands whose wives provided time diaries. Similarly, I used the fitted values for wives to impute the missing food time for wives whose husbands' time diaries are included in the ATUS03.

\section{Income, Wages and the Production of Eating, 1985 and 2003}

\section{A. Some Descriptive Statistics}

While the ultimate focus of this study is on the changing relationship between choices of household production technique and household income and time prices, an initial examination of the raw amounts of time and goods devoted to generating eating is itself inherently interesting. The final columns of Table 1 show the means and their standard deviations of various components of time and goods spent generating eating, and they break the time inputs down into those of the husband and wife. Of the 2880 minutes available to a couple in a day, the average couple spent 332 minutes, roughly 5-1/2 of its 48 available hours, in the activity eating in 1985, and 235 minutes, not quite 4 hours per day, in 2003.

The time input of the median couple is less than the average time input-the distribution is skewed rightward. In 1985 time spent actually eating meals comprised 47 percent of all time inputs into generating eating, but it had grown to 58 percent of the total by 2003 . Wives' time accounted for 63 percent of the total time input into eating in 1985 , but only 59 percent of time inputs in 2003 . Since the average spouse spends 70 to 80 minutes per day actually eating, with little difference between husbands and wives, the information on husbands' and wives' time inputs shows that husbands spent only 32 percent as much time as wives on shopping/preparation/clean-up in 1985 and only 37 percent as much in 
2003.

An interesting question is why the total time inputs into eating appear to have declined by nearly 30 percent between 1985 and 2003. One explanation might simply be that the aggregation processes that created the total eating time measures differ across the two surveys. This is possible, but the basic categories (see Appendix Table 1) seem very similar. Another possibility is that the survey methods differed and generated substantial differences in how activities are classified. This too is possible, but it is hard to believe that something as basic as eating, food shopping, and cooking and cleaning up could be classified so differently in the two sets of time diaries.

Table 1 shows that the larger decline in time use in this commodity is among wives: Their time input declined by 31 percent, husbands' by only 20 percent. The Table also shows that by far the bigger decline among wives was in the time they spent shopping/cooking/cleaning that is an input into the production of eating. Food shopping and cleaning-up especially are the kinds of secondary activity (one for which purchased inputs could be substituted—see Reid, 1934) that yield little utility and for which technical change has caused market substitutes to decrease in relative price. With rising real incomes households have become able to purchase market substitutes, which in turn have fallen in price because of substantial technical improvements (e.g., microwaves, dishwashers, etc., that spread from upper-income families across the population over this period). The substantial decline could simply reflect optimizing behavior by households in the face of rising time prices of wives and households' rising real incomes.

Table 1 also presents the order statistics of time spent on eating. What is intriguing is the great heterogeneity in the amount of time input into eating: Going from the $10^{\text {th }}$ to the $90^{\text {th }}$ percentile of the distribution of time that couples spend generating eating involves nearly quadrupling the time input, from 2 hours 40 minutes per day to 9 hours 20 minutes per day for a couple in 1985, and from 1 hour 45 minutes per day to 6 hours 35 minutes per day in 2003. Whether this heterogeneity is related to the economic determinants that affect inputs into eating is the major focus of this Section.

The average food expenditure of $\$ 4,874$ for these married couples in the CES85 constituted about 19 percent of their total expenditures, while that of married couples in the CES03 accounts for only 16 
percent of total expenditures. Like that of time inputs into eating, the distributions of goods spending are skewed to the right. The Table also breaks food expenditures down into spending on food consumed at home and that on food consumed away from home. (These figures sum to less than the total expenditure on goods inputs into eating because the total includes the other food-related purchases, mostly on capital goods, as Appendix Table 1 shows.) Food consumed away from home constitutes about one-fourth of total spending on food, and its distribution unsurprisingly exhibits much more inequality than that of food consumed at home.

Finally, Table 1 lists statistics (means and order statistics) describing total expenditures on all goods and the share of food spending from the CES85 and CES03 data. Inequality in total expenditures increased, with the coefficient of variation rising from 0.71 to 0.77 (a smaller increase in inequality of consumption than the increased income inequality over the same period, thus mirroring the relation of inequality of expenditures and incomes in the cross section shown by Dynarski et al, 1997). The increased inequality in total expenditures was concentrated entirely above the median expenditure. Indeed, while there were essentially no changes in total spending (relative to the median) at the lower percentiles, the relative change was positive above the median, with the biggest relative increase occurring at the $95^{\text {th }}$ percentile. ${ }^{8}$

\section{B. Estimating the Determinants of Goods and Time Inputs}

The first step in estimating the demand functions is the creation of the instrumental variables for household income and the prices of the spouses' time. I use household net income, thus creating an instrument for the actual amount of income at a household's disposal. The results for instrumenting net income are based on estimating regressions using the PSID86 and PSID03 data and are presented in Columns (1) and (4) of Appendix Table 3. The estimates make very good sense in light of the vast literature on income determination. Households' net incomes rise with education, especially so for husband's education (since men's age-earnings profiles rise more rapidly with education than women's,

\footnotetext{
${ }^{8}$ This corresponds perfectly to the distribution of changes in inequality in the upper tail of the distribution of men's earnings. Data from the Outgoing Rotation Groups of the CPS show that between 1979 and 2003 the 90/50 ratio rose by $25 \log$ points, but the $95 / 50$ ratio rose by $34 \log$ points.
} 
and because wives are less likely to participate in the labor force); they are quadratic in each spouse's age (again reflecting the shape of age-earnings profiles); and they are lower if young children are present, presumably indicating the impact on wives' labor-force participation.

The equations underlying the creation of instruments for husbands' and wives' values of time are the earnings equations whose estimates are shown in Columns (2), (3), (5) and (6) of Appendix Table 3. The regressions reported in Columns (2) and (5) are simple log-earnings equations including indicators of educational attainment, a quadratic in age and hours of work. Those for women also include an auxiliary selectivity equation in which the probability of working is affected by the presence of pre-school and young children, who are assumed not to affect earnings directly. The results, and the estimation itself, are completely standard and merit no further comment.

The results of the imputations in the TUS85, ATUS03 and CES85 and CES03 are presented in Table 2. For each imputation I present various order statistics and the mean and standard deviation (just as was done for the distributions of time and goods inputs in the two years in Table 1). Each imputation was made using the coefficient estimates shown in Appendix Table 3 and each observation's values of the vector of variables $\mathrm{Z} 1$ and $\mathrm{Z} 2$. To standardize the wage rates and avoid endogeneity I assume that hours of work equal 40 for all observations. (Any number could be chosen, so long as it is identical for all sample members.)

The distributions of imputed wage rates look fairly standard: Women's average imputed hourly wage rates are 64 percent of men's in 1985 and 77 percent in 2003, reflecting the well-documented increase in women's relative wages and approximating fairly closely the actual increase that occurred (Blau and Kahn, 2004).

The coefficients of variation of imputed net incomes, husband's wage rates and wife's wage rates were $0.28,0.24$ and 0.21 respectively in 1985 ; in 2003 they are $0.32,0.33$ and 0.25 respectively. All of them have increased, with the greatest increase in inequality in husband's imputed earnings. The 50/10 ratio of imputed husband's hourly wage rates was 1.40 in 1985 , but fell to 1.35 in 2003 ; the $90 / 50$ ratio rose from 1.42 to 1.50. Since Autor et al (2005) show that the biggest increase in inequality in men's 
actual earnings over this period was in the upper part of the distribution of earnings and that wage inequality in the lower half of the distribution may even have narrowed, the changing inequality in the distribution of imputed earnings accords with the facts and enhances our confidence in the instrumentalvariables approach used here.

While the distributions of imputed earnings are skewed slightly to the right, the distributions of net incomes are not skewed rightward. That there is relatively little skewness in all of the distributions of the imputed variables is the result of the fact that the distributions of returns to the unobservable determinants of wage rates and incomes, which we cannot account for, are more right-skewed than the distributions of returns to their observable determinants. Finally, it is comforting to note that the shapes of the distributions of imputed net income look quite similar across samples within years, as do the distributions of imputed wage rates.

Columns (1) and (4) in Table 3 show the results of estimating equations (2a') and (2b'), the demand functions for the inputs into the household production of eating. These relate time and goods spending to a household's position (percentile) in the distributions of imputed household net income and the spouses' imputed wage rates. While these are the central equations in the model, in the other columns I present estimates of the determinants of some of their subcomponents, including husbands' and wives' time inputs separately, and goods expenditures on food consumed at home and away from home. All of the equations include a vector of variables indicating the age distribution of children in the household. The time-demand equations also include a vector of indicators for the day of the week for which the time diary was kept. ${ }^{9}$ That the fractions of variance explained in these equations are not very high is the result of our excluding idiosyncratic variation in incomes and time prices when we necessarily use imputations for these for each household.

The estimated parameters in equation (2a'), the demand for time inputs into eating, accord completely with what we know about the relative time-intensity of the demand for eating. Higher prices of husbands' and wives' time lead them to economize on their time used in producing this commodity,

\footnotetext{
${ }^{9}$ The estimates from the ATUS03 are weighted to account for the over-sampling of weekend days, so that the results reflect a representative day.
} 
although in the estimates for 2003 the coefficients are nowhere nearly significant statistically. Moreover, we cannot reject the hypothesis that the impacts of equal-percentile increases in their time prices generate the same impact on the total time input into eating in both years. Holding time prices constant, however, a movement up the distribution of net incomes increases the time used in generating eating.

In estimating the goods-demand equations I assume that the only economic determinant is the household's net income. The results suggest that the demand for food increases with (imputed) net income, and that the demand for food eaten away from home is much more income elastic than that for food consumed at home. The income elasticities of total goods expenditure into eating (calculated around the medians) average about 0.40 , quite similar to estimates for food spending in a now-hoary literature (e.g., Houthakker and Taylor, 1966). The coefficients on income percentiles are smaller in 2003 than in 1985; given that the income distribution widened over this period, that change guarantees that the income elasticity of demand for food-related goods fell during this period.

One might be concerned that my measure of goods expenditures, which includes more than just food, may be too broad. I re-estimated the equations in Columns (1) and (4) using narrower measures, the logarithms of total food expenditures, in each year. The parameter estimates on the percentile of imputed net income are 0.00590 (s.e. $=0.00017$ ) for $1985,0.00497$ (s.e. $=0.00014$ ) for 2003 . The estimates are unsurprisingly smaller than those describing eating expenditures that include part of alcohol and appliances, but they reproduce the qualitatively similar result that the goods expenditure elasticity is lower in 2003 than in 1985.

\section{Inferring the Household Production Function}

One of the major purposes in estimating these demand equations is to examine how the relative goods intensity of eating varies along the expansion path at a point in time. Figures $1 \mathrm{a}$ and $1 \mathrm{~b}$ show how the amounts of goods and time used in producing the commodity eating increase as we move up the income distribution. Treating goods expenditures by the lowest-income household in the sample (at nearly the $0^{\text {th }}$ percentile of the distribution of imputed net income) as 100 , the calculations simply take the parameter estimates from Column (4) of Table 3 and move up the distribution of incomes by percentiles. 
The calculation of the indices of demand for time inputs into eating is more complex, as we need to account for the relationship between income and wage rates, and for the possible correlation of spouses' wage rates. To do so I estimate regressions of I on $\mathrm{W}_{\mathrm{M}}$, of $\mathrm{I}$ on $\mathrm{W}_{\mathrm{F}}$ and of $\mathrm{W}_{\mathrm{F}}$ on $\mathrm{W}_{\mathrm{M}}$. (Since these variables are percentiles and thus have the same means and standard deviations, the estimated $\mathrm{dI} / \mathrm{dW}_{\mathrm{M}}=\mathrm{dW}_{\mathrm{M}} / \mathrm{dI}$, and similarly for the other two relationships.) We can thus calculate the effect of a one-percentile increase in a household's income as:

$$
\begin{gathered}
\alpha_{\mathrm{I}}^{\prime}\left[1+\mathrm{dI} / \mathrm{dW}_{\mathrm{M}}+\mathrm{dI} / \mathrm{dW}_{\mathrm{M}}\right]+\alpha^{\prime}{ }_{\mathrm{WM}}\left[1+\mathrm{dW}_{\mathrm{M}} / \mathrm{dI}+\mathrm{dW}_{\mathrm{M}} / \mathrm{dW}_{\mathrm{M}}\right]+ \\
\alpha_{\mathrm{WF}_{\mathrm{F}}}^{\prime}\left[1+\mathrm{dW}_{\mathrm{M}} / \mathrm{dI}+\mathrm{dW}_{\mathrm{M}} / \mathrm{dW}_{\mathrm{M}}\right] .
\end{gathered}
$$

Again letting the index equal 100 at the $0^{\text {th }}$ percentile of income, I apply the changes implicit in (4) as we move up the distribution of income.

Figure 1a shows that goods spending roughly doubled (increased 101 percent) over the range of the distribution of (imputed) net incomes in 1985. Time expenditures barely increased as a household moved up the distribution of imputed net income, rising 10 percent from the bottom to the top of the distribution. Even though the three correlations that underlie the calculation in (4) are very high, a general increase in income did increase time spent in producing eating.

The results for 2003 shown in Figure 1b differ substantially from those in Figure 1a. By then the increase in goods spending as one moved up the (less equal) distribution of net incomes was relatively smaller, with an increase of only 72 percent. The gradient on time spent in eating was much steeper than in 1985, however, so that a household at the top of the distribution of imputed income spent nearly 60 percent more time on eating than one at the bottom. ${ }^{10}$

For both years the figures show that there are positive relationships between imputed net income and time and goods used in generating eating. While these suggest numerous conclusions (see below), they ignore the idiosyncratic relationship between time and goods that could exist across different households. The ATUS03 provides a unique opportunity to examine this idiosyncratic variation, as some

\footnotetext{
${ }^{10}$ If we use the narrower measure, spending only on food, the gradient for 1985 shows an increase of 81 percent from the lowest to the higher percentile of imputed net income, while that for 2003 shows an increase of 64 percent. None of the conclusions in this Part is changed in any important way if we base them on the response of this narrower concept of expenditures on eating.
} 
of the respondents in that survey can be linked to the December 2002 CPS in which a Food Security Supplement was included. That supplement included questions eliciting the amount the respondent's household spent on all food last week (the reference week), and the amount usually spent in a week. A match between the ATUS03 and the December 2002 CPS was possible for 2511 of the 9324 respondents used in the estimates presented in Table 3. The same measure of time devoted to eating was included; and for each respondent I calculated annual household spending on food based on the reference-week and usual weekly expenditures that were reported.

Because the number of matched observations was much smaller than in the other estimates for 2003, I expanded the sample by performing the same match for married couples with both partners between the ages of 18 and 64 using the 2004 American Time Use Survey and the December 2003 Food Security Supplement to the CPS. All the variables are defined and calculated as in the match for 2003, except that, absent a new round of the PSID, net income is imputed for the ATUS04 couples using the same method that generated imputed incomes in the ATUS03. This additional year of matched respondents added another 1674 couples to this data set.

Figures 2 present a view of the relationship between goods and time spending in these households using these matched data. They show the results of fitting food expenditures, first for reference-week and then for usual expenditures, to a quadratic in time use after trimming the tails of the distributions of the time and goods variables. While the confidence bands at the extremes of couples' time inputs are very wide, the sample is very sparse there: For 90 percent of the households the logarithm of food time is between 4.5 and 6 , where the confidence bands are much narrower. The relationships implicit in these figures corroborate the conclusions from the estimation and Figures 1: Those households in which the couple spends more time in eating-related activities are also those in which more money is spent on food (where in these data food no longer includes prorated amounts of spending on food-related appliances)..

To separate out the idiosyncratic part of the relationship from the part due to variations in observables (in imputed net income), in Table 4 I present estimates of equations describing the logarithms of the expenditure measures (again for the trimmed samples). Columns (1) and (4) of the Table 
corroborate the results in Figures 2, as they show positive and nearly statistically significant relationships between time spent and goods expenditures on food. Columns (2) and (5) merely replicate the unsurprising finding in Table 3 that expenditures on food increase with imputed net income. Columns (3) and (6) show that, even accounting for differences in imputed net incomes, those couples that spend more time in eating activities also spend more money on food. The idiosyncratic components of goods spending and time use are positively related. Taken together, Figures 2 and Table 4 suggest that the implied positive relationship between time and goods spending on eating is not an artifact of our imputations that necessarily base the relationship only on observables.

With data on the same households' goods and time inputs into eating we can estimate a simple formal household-production relationship to infer the ease of substitution between goods and time. Assuming that the household production function for eating is CES, we can write the relative demand function as:

$$
\ln (\mathrm{X} / \mathrm{T})=\text { Constant }+\sigma \ln \left(\rho \mathrm{W}_{\mathrm{M}}+[1-\rho] \mathrm{W}_{\mathrm{F}}\right),
$$

where $\sigma$ is the elasticity of substitution between goods and time, and $\rho$ is the weight on the husband's price of time that is implicit in the household's decisions about goods-time substitution. I estimate (5) by nonlinear least squares and present the parameter estimates in Columns (4) and (8) of Table 4. We cannot reject the hypothesis that $\rho=.5$-that the household weights both spouses' prices of time equally in choosing goods and time inputs. This is an anomalous result, although given that relatively little of the time input into eating consisted of the wife's food shopping/cooking/cleaning by 2003, it is less surprising than it might appear at first glance. Most important, the elasticity of substitution is quite low and consistently so whether one uses reported reference-week food expenditures or usual food expenditures. Clearly, this direct evidence on household production suggests that for this particular commodity the substitution of goods for time is not easy.

In Table 5 I summarize the results underlying Figure 1. The top part of the table shows the real goods (dollars per year) and time inputs (converted from minutes per day to hours per year to increase comparability to the annual expenditure measures). It also presents the goods/time ratio at various 
percentiles of the distribution of imputed net incomes for each year, and it lists the percentage changes in this ratio over the eighteen-year period. To make the expenditure data comparable across years the spending data for 1985 are converted by the PCE deflator for food to 2003 dollars. ${ }^{11}$ The bottom part of the table lists the same information at the actual means and medians of net incomes, goods spending and time use. These latter correspond fairly closely to the ratios and changes at the measures of central tendency based on our calculations of imputed net income and wage rates.

The statistics in Table 1 and the estimates presented in Figures 1 and 2 and in Tables 3 and 4 suggest the following central conclusions:

1. In both 1985 and 2003 both goods expenditures and time inputs into eating rose with income.

2. Between 1985 and 2003 total time spent in eating fell sharply while goods spending declined relative to all expenditures and stayed essentially constant in real terms.

3. Consequently, over this period the relative goods intensity of eating rose at the mean and at all other points of the distribution of net incomes.

4. The relative goods intensity of eating rose most sharply in the lower part of the distribution of net income, with the rate of increase declining steadily as one moves up the distribution.

5. The direct evidence for 2003-04 implies that goods and time inputs into eating are positively correlated within households.

6. The direct evidence also suggests that substitution between goods and time in producing eating is not easy.

What does this combination of findings tell us about the nature of the household production function for eating? What minimal reasonable set of inferences about the nature of that production function is suggested by the results? The two sets of cross-section results match expectations: Those households with higher full incomes produce this commodity more goods-intensively than those in which the spouses' time prices and full incomes are lower. While the results in Table 3 demonstrated that a higher price of time (especially the wife's time) leads to substitution against time used in producing

\footnotetext{
${ }^{11}$ Using the CPI Food and Beverages price index lowers the percentage increases in X/T, with the increase at the $5^{\text {th }}$ percentile of the distribution of imputed income becoming 47.9 percent and that at the $95^{\text {th }}$ percentile becoming -8.3 percent.
} 
eating, the positive income effects lead higher-income couples to devote more time to eating (in combination with their greater goods purchases). This result suggests that it is relatively difficult for people to substitute goods for time in the production of this commodity compared to the composite of all other commodities, an inference that is corroborated by the direct estimates for 2003-04. Despite the common use of the production of eating to illustrate goods-time substitution, it appears that by the early $21^{\text {st }}$ century households had taken advantage of most of the opportunities for such substitution.

The changes in the relative goods-intensity of production across the changing income distribution are more difficult to reconcile. If, however, the household production function for eating is heterothetic, and goods-time substitution becomes more difficult moving out along the expansion path, then we would expect to observe the greater cut in time inputs into eating in lower-income households that we have in fact seen between 1985 and 2003. Implicitly the difficulty of substituting goods for time in the production of the other, composite commodity does not increase as rapidly as production expands. Higher-income families, which experienced the largest increases in income over this period, thus found it increasingly difficult to expand the production of this commodity by increasing its goods intensity.

One could also explain the results by technical change in the production of meals (preparation, shopping and cleaning). Indeed, even the relative decline in time inputs at the lower end of the income distribution might be explicable if one could demonstrate that there was more rapid time-saving technical change in the sub-aggregates of those categories that are used particularly by lower-income households. In the end, both biased technical change and heterothetic production without biased technical change are consistent with the findings. ${ }^{12}$

The results on goods used in producing eating suggest a weakening positive relation to net incomes over this period. Even though the distribution of income became less equal, the results show very clearly that that the effect of a one-percentile increase in income diminished over the two decades. Rising income inequality did not lead to rising inequality in food consumption. However, time inputs

\footnotetext{
${ }^{12}$ Taking an approach outside the theory of household production, one might also interpret the steeper food-time income gradient as reflecting the conjunction of a positive income elasticity of demand for family time together (spent eating) and the rise in income inequality. This consumption-based interpretation cannot, however, explain why the goods-income gradient has become flatter and, indeed, seems inconsistent with it.
} 
into eating became more positively correlated with net income over this period, so that changes in the use of time added to the inequality in the amount of this commodity that was produced. It is thus unclear whether inequality in production/consumption of the commodity "eating" increased or decreased, since we can infer the general shape of the production function only for 2003-04 and cannot observe how it may have changed over the two decade.

\section{Conclusions}

In this study I have examined the determinants of the household production function characterizing eating, a commodity whose production involves using purchased food and some capital goods in conjunction with time spent preparing the food, eating it and cleaning up afterwards. Particular attention has been paid to ensuring that the economic variables that determine how different households produce this commodity are truly exogenous - uncontaminated by the simultaneous determination of time spent in producing the commodity and time spent in generating earnings. The results show a large decrease over time in the time inputs into eating - a rise in its goods-intensity. Eating appears to be a relatively goods-intensive commodity, one in which the substitution of goods for time as incomes and time prices rise is relatively difficult and becomes even more difficult as more is produced.

Taken together the results in Section IV offer some insights into likely changes in the demand for goods used in producing the commodity eating as incomes and time prices rise-most important, in the demand for food. In particular, if, as the findings indicate, goods-time substitution is difficult and becomes increasingly difficult as production of the commodity expands, we should expect spending on food to rise even more slowly than a simple consideration of the income elasticity of demand for expenditures on food would suggest. If the growing inequality in incomes and time prices that we have observed for the past three decades ceases and even begins to reverse, the cost of substituting services (of lower-wage workers) for time (by higher-wage consumers) will rise, making it even harder to increase the goods-time ratio and even less likely that spending on goods that are q-complementary with time in producing eating will rise. Taken together, these considerations suggest that Americans' food expenditures will rise more slowly than might be indicated by standard forecasts based solely on the 
demand for goods.

Beginning with Altonji (1986) economists have used spending on food, which is readily available in household surveys that concentrate on measuring income, such as the PSID, as a proxy to identify inter-temporal substitution in labor supply. While some difficulties with focusing on food spending because of its income inelasticity have been pointed out (Attanasio and Weber, 1995), the approach here shows that the problems go deeper. In particular, because the commodity eating apparently is full-income inelastic, and because the household production function for eating exhibits less substitutability between goods and time than is true for household production generally, goods expenditures on food are systematically related nonlinearly to the prices of time. Using any measure of goods expenditures in this context will induce biases unless it describes spending on goods that are used in the household production of a representative commodity.

I have implicitly treated the household in the context of a unitary model of decision-making. That is undoubtedly a restrictive assumption, as evidence for goods expenditures and time use separately suggests that their use is often better described by a collective model (Pollak, 2005). A profitable, although far from trivial extension of this study would consider the joint demand for goods and time in the context of a model of household production based on collective decision-making.

The exercise conducted here could (and should) be done (with varying amounts of effort) for other commodities that are produced at home to examine how their production has changed over time and as distributions of earnings and income have changed. Indeed, one can envision a complete system of demand and household production equations that defines commodities a priori, accounts for all goods expenditures and all uses of (non-market) time and examines how each is affected by incomes and time prices. With the development of a comprehensive and continuing time-use survey in the United States (the ATUS) there is every reason to begin estimating household production technologies using methodologies similar to those that have been used for so long in describing the production of goods. 


\section{REFERENCES}

Mark Aguiar and Eric Hurst, "Consumption vs. Expenditure," Journal of Political Economy, 113 (Oct. 2005): 919-948.

Joseph Altonji, "Intertemporal Substituion in Labor Supply: Evidence from Micro Data," Journal of Political Economy, 94 (June 1986): S176-S215.

Joshua Angrist and Alan Krueger, "The Effect of Age at School Entry on Educational Attainment: An Application of Instrumental Variables with Moments from Two Samples," Journal of the American Statistical Association, 87 (June 1992): 328-336.

Orazio Attanasio and Guglielmo Weber, "Is Consumption Growth Consistent with Intertemporal Optimization? Evidence from the Consumer Expenditure Survey," Journal of Political Economy, 103 (December 1995): 1121-1157.

David Autor, Lawrence Katz and Melissa Kearney, "Rising Wage Inequality: The Role of Composition and Prices," National Bureau of Economic Research, Working Paper No. 11628, 2005.

Gary Becker, “A Theory of the Allocation of Time,” Economic Journal, 75 (September 1965): 493-517.

Jeff Biddle and Daniel Hamermesh, "Sleep and the Allocation of Time," Journal of Political Economy, 98 (October 1990): 922-43.

Jeff Biddle and Gary Zarkin, "Choice Among Wage-Hours Packages: An Empirical Investigation of Male Labor Supply,” Journal of Labor Economics, 7 (October 1989): 415-437.

Francine Blau and Lawrence Kahn, "The US Gender Pay Gap in the 1990s," National Bureau of Economic Research, Working Paper No. 10853, October 2004.

Thomas Crossley and Yuqian Lu, "Exploring the Returns-to-Scale in Food Preparation," McMaster University, Department of Economics, Working Paper 2004-06.

Susan Dynarski and Jonathan Gruber, "Can Families Smooth Variable Earnings," Brookings Papers on Economic Activity, No. 1 (1997): 229-303.

Peter Gottschalk and Timothy Smeeding, "Empirical Evidence on Income Inequality in Industrial Countries," in Anthony Atkinson and François Bourgignon, eds., Handbook of Income Distribution. Amsterdam: Elsevier, 2000, pp. 261-307.

Peter Gottschalk and Susan Mayer, "Changes in Home Production and Trends in Economic Inequality," in Daniel Cohen, Thomas Piketty and Gilles Saint-Paul, The Economics of Rising Inequalities. Oxford: Oxford University Press, 2002

Reuben Gronau, "Wage Comparisons-A Selectivity Bias," Journal of Political Economy, 82 (November 1974): 1119-1143.

, "Home Production: A Forgotten Industry," Review of Economics and Statistics, 62 (August 1980): 408-416.

and Daniel Hamermesh, "Time vs. Goods: The Value of Measuring Household Technologies," Review of Income and Wealth, 52 (March 2006), forthcoming. 
Daniel Hamermesh, "Consumption and Retirement: The Missing Link in the Life Cycle," Review of Economics and Statistics, 66 (February 1984): 1-7.

--------------, “Timing, Togetherness and Time Windfalls," Journal of Population Economics, 15 (November 2002): 601-623.

James Heckman, "Sample Selection Bias as a Specification Error," Econometrica, 47 (January 1979): 153-162.

Michael Horrigan and Diane Herz, "A Study in the Process of Planning, Designing and Executing a Survey Program: The BLS American Time-Use Survey," in Daniel Hamermesh and Gerard Pfann, eds., The Economics of Time Use. Amsterdam: North Holland, 2005.

Hendrik Houthakker and Lester Taylor, Consumer Demand in the United States. Cambridge, MA: Harvard University Press, 1966.

Sébastien Lecocq, "The Allocation of Time and Goods in Household Activities: A Test of Separability," Journal of Population Economics, 14 (2001): 585-97.

Robert Pollak, "Bargaining Power in Marriage: Earnings, Wage Rates and Household Production," National Bureau of Economic Research, Working Paper No. 11239, 2005.

Margaret Reid, Economics of Household Production. London: Chapman and Hall, 1934.

John Robinson and Geoffrey Godbey, Time for Life: The Surprising Ways Americans Use Their Time, $2^{\text {nd }}$ ed. University Park, PA: Pennsylvania State University Press, 1999.

Daniel Slesnick, "Gaining Ground: Poverty in the Postwar United States," Journal of Political Economy, 101 (Feb. 1993): 1-38.

Victoria Vernon, Household Economies of Scale, Food Consumption and Intra-Household Allocation of Time, Chapter 3. Unpublished Doctoral Dissertation, University of Texas, 2004. 
Table 1. Statistics Describing Households' Eating Time and Goods Expenditures, 1985 and 2003

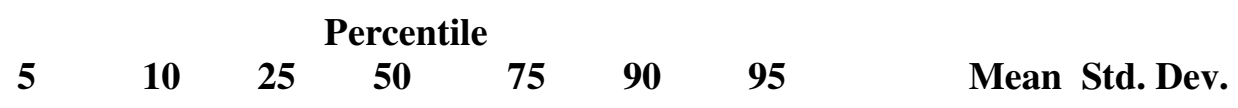

Time (minutes/day), $\mathrm{N}=688 *$ :

$\begin{array}{lrrrrrrrrr}\text { Total } & 121 & 160 & 224 & 313 & 405 & 559 & 639 & 331.8 & (154.1) \\ & & & & & & & & & \\ \text { Husband } & 30 & 44 & 70 & 105 & 160 & 233 & 287 & 124.2 & (82.4) \\ \text { Eating } & 20 & 30 & 50 & 70 & 105 & 140 & 180 & 81.6 & (47.2) \\ & & & & & & & & & \\ \text { Wife } & 50 & 80 & 125 & 193 & 271 & 362 & 416 & 207.7 & (110.6) \\ \text { Eating } & 16 & 25 & 45 & 70 & 95 & 135 & 165 & 75.4 & (45.8)\end{array}$

Goods (dollars/year), $\mathrm{N}=\mathbf{1 1 , 4 1 8}$ :

\begin{tabular}{|c|c|c|c|c|c|c|c|c|c|}
\hline Total & $\$ 1648$ & 2160 & 3039 & 4320 & 6036 & 8067 & 9663 & 4874 & (2868) \\
\hline Home & $\$ 1020$ & 1356 & 2040 & 2928 & 4104 & 5280 & 6120 & 3187 & (1648) \\
\hline Away & $\$ 0$ & 0 & 300 & 666 & 1200 & 2400 & 3000 & 996 & (1178) \\
\hline Total expenditure & $\$ 8283$ & 10,382 & 14,748 & 21,295 & 30,985 & 47,353 & 61,740 & 26,069 & (18634) \\
\hline $\begin{array}{l}\text { Relative to } \\
\text { Median }\end{array}$ & 0.389 & 0.488 & 0.693 & 1.000 & 1.455 & 2.224 & 2.899 & & \\
\hline $\begin{array}{l}\text { Food share } \\
\text { (at percentiles o }\end{array}$ & $\begin{array}{l}.278 \\
\text { of total } \mathrm{e}\end{array}$ & $\begin{array}{c}.262 \\
\text { penditu }\end{array}$ & .232 & .196 & .153 & .120 & .091 & .193 & $(0.099)$ \\
\hline
\end{tabular}

\section{3}

Time (minutes/day), N = 9324*:

\begin{tabular}{|c|c|c|c|c|c|c|c|c|c|}
\hline Total & 80 & 105 & 155 & 225 & 305 & 395 & 455 & 235.4 & $(115.4)$ \\
\hline Husband total & 10 & 25 & 50 & 90 & 135 & 190 & 230 & 99.6 & (71.6) \\
\hline Eating & 0 & 15 & 30 & 60 & 95 & 135 & 160 & 71.7 & $(51.5)$ \\
\hline Wife total & 25 & 45 & 80 & 130 & 190 & 260 & 315 & 143.8 & (91.4) \\
\hline Eating & 0 & 15 & 30 & 60 & 90 & 130 & 156 & 68.9 & $(50.1)$ \\
\hline \multicolumn{10}{|c|}{ Goods (dollars/year), N = 16,596: } \\
\hline Total & $\$ 2786$ & 3453 & 4746 & 6663 & 9240 & 12,473 & 15,060 & 7576 & $(4545)$ \\
\hline Home & $\$ 2028$ & 2360 & 3380 & 4680 & 6240 & 8320 & 9880 & 5127 & $(2752)$ \\
\hline Away & $\$ 0$ & 0 & 480 & 1200 & 2400 & 4200 & 5756 & 1884 & (2650) \\
\hline Total expenditur & re $\$ 16,428$ & 820,198 & 28,729 & 42,599 & 64,286 & 98,263 & 131,119 & 53,847 & $(41,744)$ \\
\hline $\begin{array}{l}\text { Relative to } \\
\text { Median }\end{array}$ & 0.386 & 0.474 & 0.674 & 1.000 & 1.509 & 2.307 & 3.078 & & \\
\hline $\begin{array}{l}\text { Food share } \\
\text { (at percentiles }\end{array}$ & $\begin{array}{c}.247 \\
\text { of total e }\end{array}$ & $\begin{array}{l}.233 \\
\text { expenditu }\end{array}$ & .195 & .154 & .125 & .105 & .082 & .162 & $(0.087)$ \\
\hline
\end{tabular}

*Means are based on time use on a representative day. 
Table 2. Statistics Describing Imputed Net Income and Prices of Time, 1985 and 2003

\begin{tabular}{|c|c|c|c|c|c|c|c|c|c|}
\hline & & & & Percenti & & & & & \\
\hline & 5 & 10 & 25 & 50 & 75 & 90 & 95 & Mean & Std. Dev \\
\hline 1985 & & & & & & & & & \\
\hline From TUS & & & & & & & & & \\
\hline Imputed & & & & & & & & & \\
\hline Net income & $\$ 21,295$ & 24,781 & 30,909 & 40,267 & 46,923 & 54,540 & 58,205 & 39,433 & (11224) \\
\hline $\mathrm{W}_{\mathrm{M}}$ & $\$ 7.14$ & 7.58 & 8.42 & 10.50 & 12.36 & 14.96 & 15.49 & 10.75 & $(2.62)$ \\
\hline $\mathrm{W}_{\mathrm{F}}$ & $\$ 5.10$ & 5.27 & 6.07 & 6.63 & 7.85 & 9.31 & 9.66 & 6.95 & $(1.41)$ \\
\hline
\end{tabular}

\section{From CES85:}

Imputed

Net income

$\$ 18,464 \quad 23,187 \quad 30,101 \quad 38,894 \quad 46,521 \quad 54,673 \quad 57,843$

$38,494 \quad(11897)$

$\begin{array}{llllllllll}\mathrm{W}_{\mathrm{M}} & \$ 6.89 & 7.52 & 8.37 & 10.55 & 12.31 & 14.96 & 15.49 & 10.69 & (2.67)\end{array}$

$\begin{array}{llllllllll}\mathrm{W}_{\mathrm{F}} & \$ 4.92 & 5.16 & 5.92 & 6.63 & 7.85 & 9.31 & 9.61 & 6.89 & (1.44)\end{array}$

2003

From ATUS03:

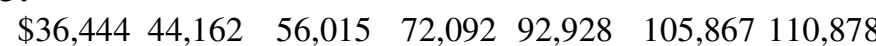

$73,570 \quad(23444)$

Net income

$\mathrm{W}_{\mathrm{M}}$

$\begin{array}{lllllll}\$ 11.03 & 12.10 & 14.42 & 16.63 & 22.16 & 24.46 & 24.76\end{array}$

$17.67 \quad(4.52)$

$\mathrm{W}_{\mathrm{F}}$

$\begin{array}{lllllll}\$ 8.80 & 9.63 & 11.46 & 13.19 & 17.56 & 18.82 & 19.00\end{array}$

$13.87 \quad(3.40)$

\section{From CES03:}

Imputed

Net income

$\mathrm{W}_{\mathrm{M}}$

$\mathrm{W}_{\mathrm{F}}$

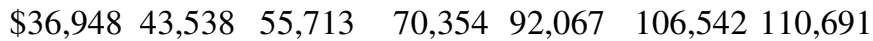

$\begin{array}{lllllll}\$ 11.11 & 12.10 & 14.40 & 16.30 & 22.02 & 24.51 & 24.76\end{array}$

$\begin{array}{lllllll}\$ 8.80 & 9.27 & 11.45 & 13.01 & 17.09 & 18.78 & 19.00\end{array}$
$72,944 \quad(23237)$

$17.52 \quad(4.51)$

$13.59 \quad(3.33)$ 
Table 3. Regression Estimates, Determinants of Logarithms of Eating Time and Goods Expenditures, TUS85 $(\mathrm{N}=688)$ and CES85 $(\mathrm{N}=11,418)$, ATUS03 $(\mathrm{N}=9324)$ and CES03 $(\mathrm{N}=16,596) *$

\begin{tabular}{|c|c|c|c|c|c|c|c|}
\hline & \multicolumn{3}{|c|}{ Time (Ln(Minutes)) } & & \multicolumn{3}{|c|}{ Goods (Ln(Expenditures)) } \\
\hline & Total & Husband & Wife & & Total & Home & Away \\
\hline & (1) & (2) & (3) & 1985 & (4) & (5) & (6) \\
\hline $\begin{array}{l}\text { Net income } \\
\text { percentile }\end{array}$ & $\begin{array}{c}0.0108 \\
(0.0025)\end{array}$ & $\begin{array}{c}0.0066 \\
(0.0029)\end{array}$ & $\begin{array}{c}0.0028 \\
(0.0017)\end{array}$ & & $\begin{array}{c}0.00702 \\
(0.00018)\end{array}$ & $\begin{array}{c}0.00439 \\
(0.00020)\end{array}$ & $\begin{array}{c}0.02032 \\
() .00076)\end{array}$ \\
\hline $\begin{array}{l}\mathrm{W}_{\mathrm{M}} \\
\text { percentile }\end{array}$ & $\begin{array}{l}-0.0067 \\
(0.0020)\end{array}$ & $\begin{array}{l}-0.0048 \\
(0.0028)\end{array}$ & & & & & \\
\hline $\begin{array}{l}\mathrm{W}_{\mathrm{F}} \\
\text { percentile }\end{array}$ & $\begin{array}{l}-0.0044 \\
(0.0012)\end{array}$ & & $\begin{array}{l}-0.0031 \\
(0.0016)\end{array}$ & & & & \\
\hline Adjusted $\mathrm{R}^{2}$ & 0.0432 & 0.0207 & 0.0022 & & 0.1607 & 0.1153 & 0.0726 \\
\hline & & & & 2003 & & & \\
\hline $\begin{array}{l}\text { Net income } \\
\text { percentile }\end{array}$ & $\begin{array}{c}0.00204 \\
(0.00051)\end{array}$ & $\begin{array}{l}0.00183 \\
(0.00043)\end{array}$ & $\begin{array}{c}0.00197 \\
(0.00031)\end{array}$ & & $\begin{array}{c}0.00543 \\
(0.00014)\end{array}$ & $\begin{array}{c}0.00298 \\
(0.00017)\end{array}$ & $\begin{array}{c}0.02110 \\
() .00067)\end{array}$ \\
\hline $\begin{array}{l}\mathrm{W}_{\mathrm{M}} \\
\text { percentile }\end{array}$ & $\begin{array}{l}-0.000078 \\
(0.00043)\end{array}$ & $\begin{array}{l}-0.000035 \\
(0.00043)\end{array}$ & & & & & \\
\hline $\begin{array}{l}\mathrm{W}_{\mathrm{F}} \\
\text { percentile }\end{array}$ & $\begin{array}{l}-0.00024 \\
(0.00031)\end{array}$ & & $\begin{array}{l}-0.00023 \\
(0.00031)\end{array}$ & & & & \\
\hline Adjusted $\mathrm{R}^{2}$ & 0.0096 & 0.0096 & 0.0097 & & 0.1234 & 0.0730 & 0.0631 \\
\hline
\end{tabular}

*Standard errors in parentheses here and in Table 4. The estimating equations all include measures of the number of children under age 6 , and between ages 6 and 17. The equations describing time use also include indicators for the day of the week on which the time diary was kept. 

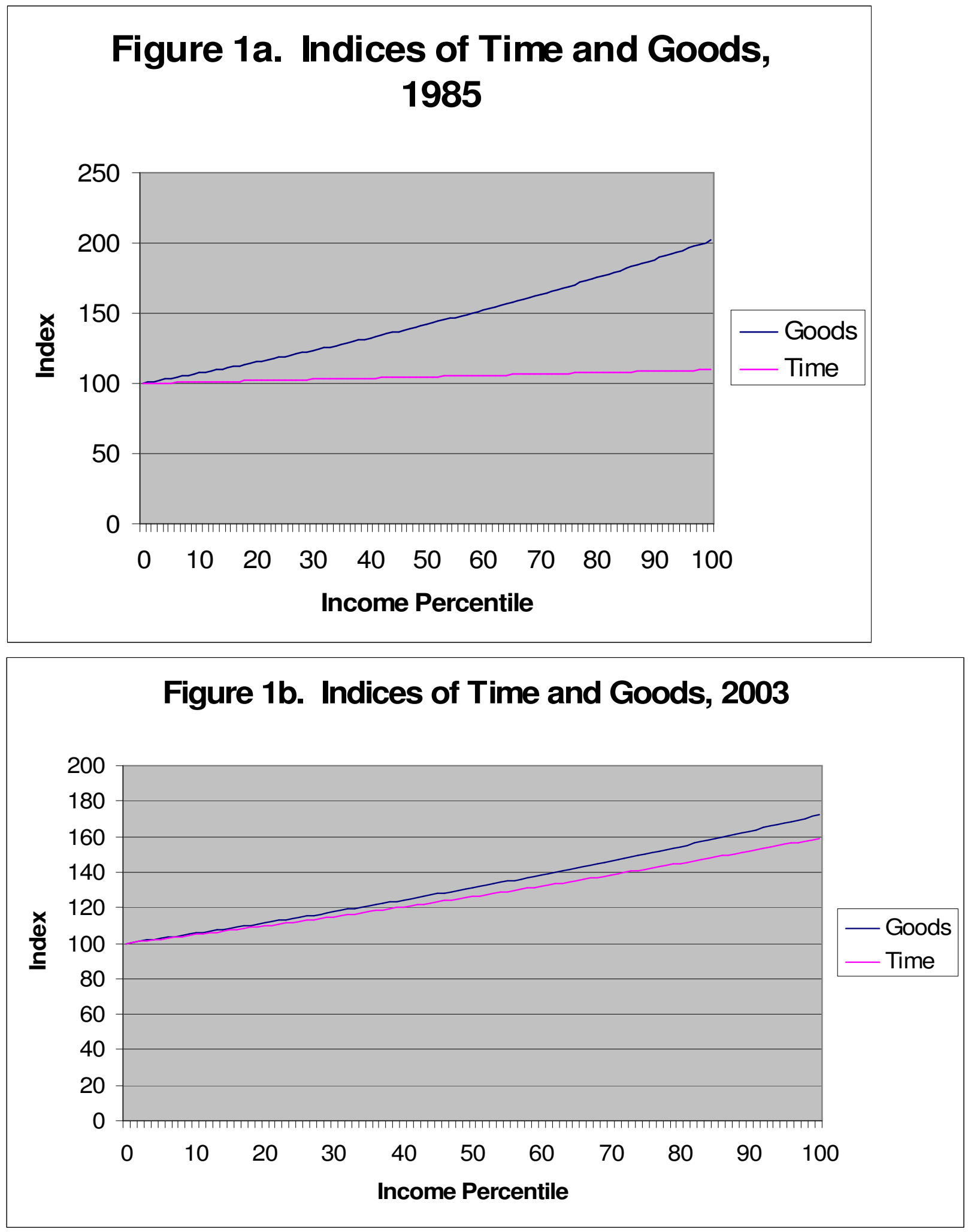
Figure 2a. Quadratic Prediction of Reference-week Food Expenditures from Food Time, Matched ATUS and Food Security Supplement Data

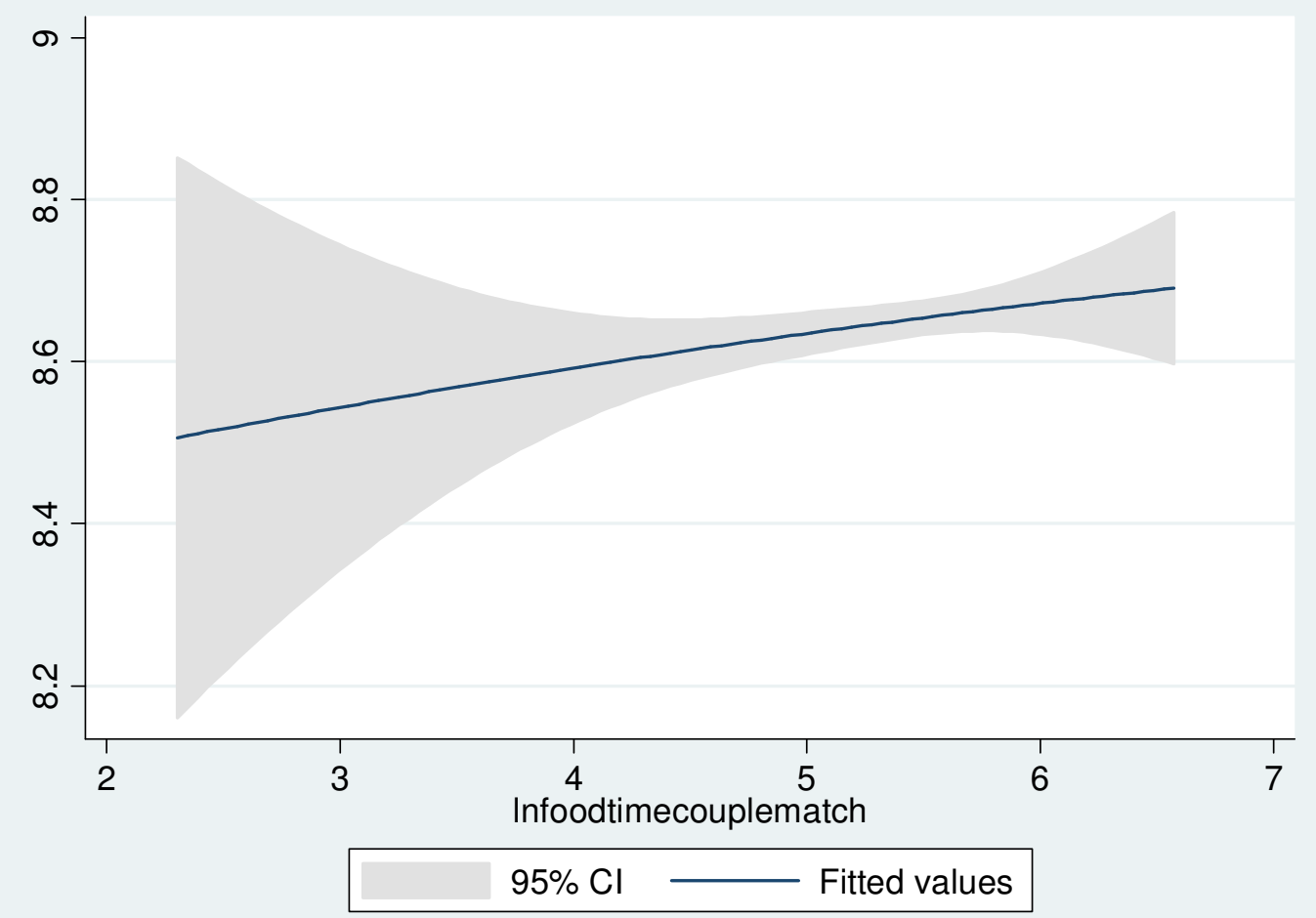

Figure 2b. Quadratic Prediction of Usual Food Expenditures from Food Time, Matched ATUS and Food Security Supplement Data

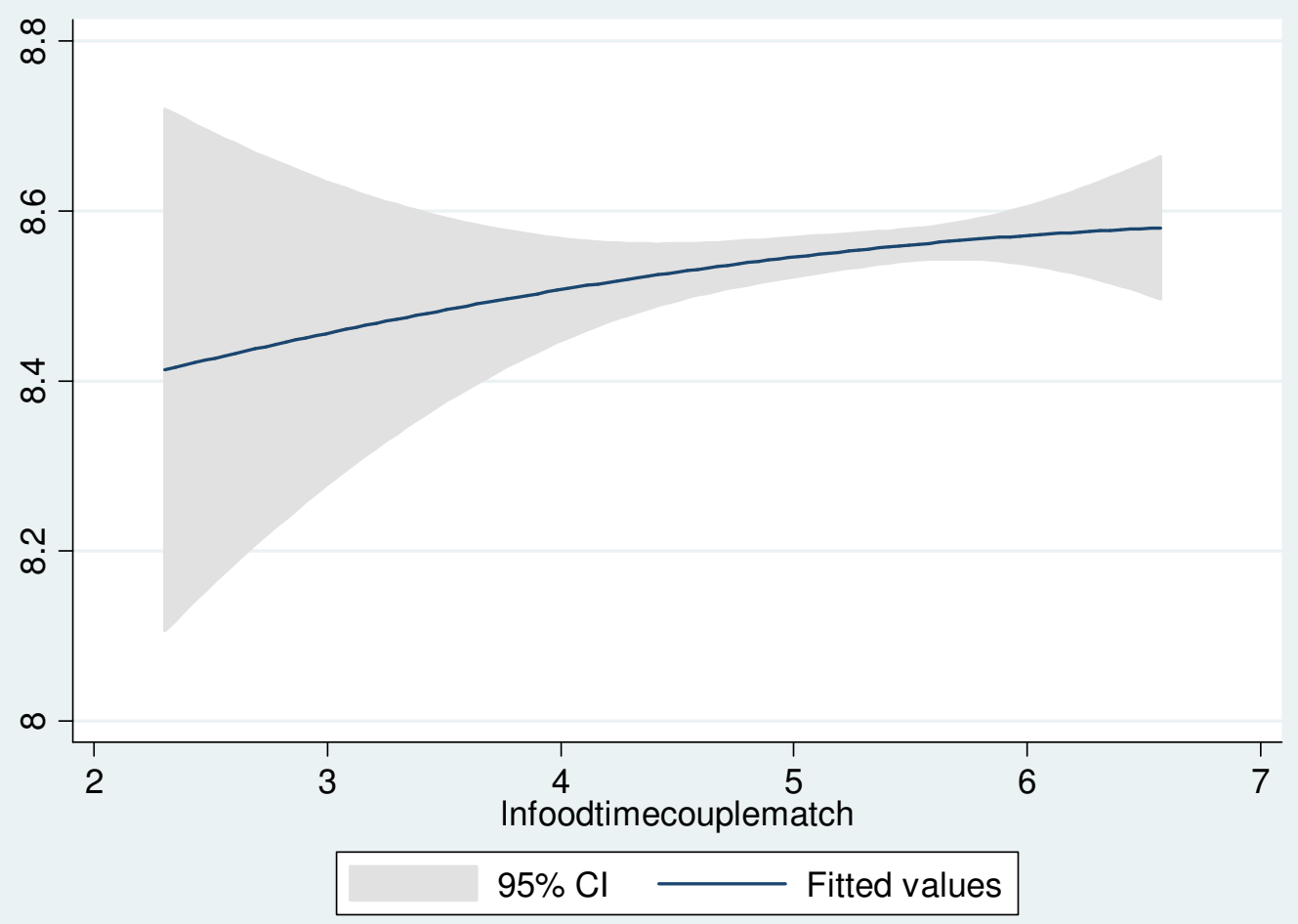


Table 4. Regression Estimates, Determinants of Logarithms of Eating Time and Goods Expenditures, Merged ATUS03 and December 2002 CPS Food Security Supplement, ATUS04 and December 2003 CPS Food Security Supplement (N=3737)*

\section{Reference-week Food Expenditures}

(1)

(2)

(3)

0.0232

(0.0199)

$\operatorname{Ln}($ Net income $)$

(0.0194)

$$
0.3223 \quad 0.3196
$$

(4)

(5)

0.0281

(0.0173)

\section{Usual Food Expenditures}

(6)

0.0177

(0.0172)

$\begin{array}{cl}0.2371 & 0.2354 \\ (0.0255) & (0.0256)\end{array}$

$\rho$$$
\text { (0.0283) (0.0284) }
$$

0.181

$(0.150)$

0.341

(0.331)
0.646

$(0.191)$

0.316

$(0.142)$

$\begin{array}{lllllllll}\text { Adjusted } \mathrm{R}^{2} & 0.0068 & 0.0388 & 0.0389 & 0.0123 & 0.0083 & 0.0301 & 0.0301 & 0.0074\end{array}$

*The estimating equations all include measures of the number of children under age 6, and between ages 6 and 17 . The samples are trimmed to remove 2.5 percent tails of eating time and eating expenditures. In Columns (1)-(3) and (5)-(7) the dependent variable is the logarithm of food expenditures; in Columns (4) and (8) it is the logarithm of the ratio of food expenditures to time spent on food. 
Table 5. Annual Goods (dollars) and Time (hours) Spent on Eating Production, 1985 and 2003, at Points on the Distributions of Imputed and Actual Household Incomes ${ }^{\mathrm{a}}$

\begin{tabular}{|c|c|c|c|}
\hline $\begin{array}{l}\text { Percentile } \\
\text { and } \\
\text { Year }\end{array}$ & $\mathbf{X}$ & $\mathbf{T}$ & $\begin{array}{c}\mathbf{X} / \mathbf{T} \\
(\$ / \text { hour }\end{array}$ \\
\hline
\end{tabular}

$\begin{array}{ccccc}\begin{array}{c}\text { Imputed Income } \\ 5^{\text {th }} \\ 1985\end{array} & \$ 4379 & 1716 & 2.55 & \\ 2003 & 4677 & 1166 & 4.05 & 58.66 \\ & & & & \\ 10^{\text {th }} & & & & \\ 1985 & 4536 & 1724 & 2.63 & \\ 2003 & 4805 & 1184 & 4.07 & 54.50 \\ & & & & \\ 25^{\text {th }} & & & & \\ 1985 & 5040 & 1748 & 2.88 & \\ 2003 & 5214 & 1241 & 4.11 & 42.67 \\ & & & & \\ 50^{\text {th }} & & & & \\ 1985 & 6008 & 1789 & 3.36 & \\ 2003 & 5973 & 1342 & 4.20 & 24.94 \\ & & & & \\ 75^{\text {th }} & & & & \\ 1985 & 7161 & 1831 & 3.91 & \\ 2003 & 6842 & 1450 & 4.28 & 9.40 \\ 90^{\text {th }} & & & & \\ 1985 & 7957 & 1856 & 4.29 & \\ 2003 & 7422 & 1520 & 4.33 & 1.09 \\ & & & & \\ 95^{\text {th }} & & & & \\ 1985 & 8241 & 1865 & 4.42 & \\ 2003 & 7627 & 1544 & 4.35 & -1.62\end{array}$

\section{Actual Income}

Mean

$\begin{array}{llll}1985 & 7767 & 2018 & 3.85\end{array}$

$\begin{array}{lllll}2003 & 7576 & 1432 & 5.29 & 37.48\end{array}$

Median

$\begin{array}{lllll}1985 & 7384 & 1904 & 3.62 & \\ 2003 & 6663 & 1369 & 4.87 & 34.63\end{array}$

${ }^{\text {a }}$ Predicted goods expenditures are all in 2003 dollars using the PCE deflator for food expenditures. Expenditures are annual, time is annual hours. 


\section{Appendix Table 1. Definitions_Eating Time and Goods Expenditure Categories, 1985 and 2003}

\begin{tabular}{|l|l|l|l|}
\multicolumn{1}{c}{ TUS85 } \\
\begin{tabular}{|l} 
Activity \\
Code
\end{tabular} \\
\begin{tabular}{|l|l|l|l|}
\hline Meals at work & 6 & Eat/drink as part of job & \multicolumn{1}{c|}{$\begin{array}{c}\text { Activity } \\
\text { Code }\end{array}$} \\
\hline Meal preparation; meal clean-up & 10,11 & $\begin{array}{l}\text { Food \& drink preparation, presentation } \\
\text { and clean-up }\end{array}$ & $0202 .$. \\
\hline $\begin{array}{l}\text { Groceries, supermarket shopping for } \\
\text { food }\end{array}$ & 30 & $\begin{array}{l}\text { Grocery shopping; purchasing non- } \\
\text { grocery food }\end{array}$ & 070101 \\
070103
\end{tabular} \\
\hline $\begin{array}{l}\text { Travel related to outside activities } \\
\text { prorated by share of outside activities } \\
\text { that are grocery shopping }\end{array}$ & 39 & $\begin{array}{l}\text { Travel to/from grocery store; waiting } \\
\text { associated with shopping prorated by } \\
\text { grocery and non-grocery food shopping } \\
\text { shares in all shopping }\end{array}$ & $\begin{array}{l}070105 \\
\text { prorated; } \\
170701\end{array}$ \\
\hline $\begin{array}{l}\text { Meals, snacks at home; meals, snacks } \\
\text { away from home }\end{array}$ & 43,44 & $\begin{array}{l}\text { Eating and drinking } \\
11 \ldots .\end{array}$ \\
\hline
\end{tabular}

CES85

\section{GOODS}

\begin{tabular}{|l|l|}
\hline Food & Food \\
\hline $.5^{*}$ Alcohol & $.5^{*}$ Alcohol \\
\hline $\begin{array}{l}.333^{*}(\text { Major appliances }+ \text { miscellaneous } \\
\text { appliances) }\end{array}$ & $\begin{array}{l}.333^{*} \text { (Major appliances }+ \text { miscellaneous } \\
\text { appliances) }\end{array}$ \\
\hline Small appliances & Small appliances \\
\hline
\end{tabular}




\section{Appendix Table 2. Data Sets Used-Main and for Imputation}

\section{MAIN}

Time Use Survey,

Univ. of Maryland

(TUS85

Consumer Expenditure Survey,

BLS

(CES85)

1985

\section{IMPUTATION}

Currently Population Survey, Merged Outgoing Rotation

Groups, BLS

(CPS-MORG85)

University of Mchigan Panel Study of Income Dynamics (PSID86)

2003

American Time Use Survey,

BLS

(ATUS03)

Currently Population Survey, Merged Outgoing Rotation

Groups, BLS

(CPS-MORG03)

Consumer Expenditure Survey,

BLS

(CES03)

University of Michigan Panel Study of Income Dynamics (PSID03)

ATUS03 and December 2002 CPS

Food Security Supplement

2004

ATUS04 and December 2003 CPS

Currently Population Survey, Merged Outgoing Rotation

Groups, BLS

(CPS-MORG04) 


\title{
Appendix Table 3. First-Round Estimates of Net Income and the Price of Husbands' and Wives'
} Time, PSID 1986 and 2003, CPS-MORG 1985 and 2003*

\section{5 \\ Dep. Var.: Net Income $\operatorname{Ln}(\mathrm{WM})$ \\ $\operatorname{Ln}(\mathbf{W F})$ \\ Net Income $\quad \operatorname{Ln}(\mathrm{WM}) \quad \operatorname{Ln}(\mathrm{WF})$}

(1)

(2)

Husband:

Educ. 9-11

$\begin{array}{cc}-6662.60 & -0.256 \\ (521.57) & (0.0061)\end{array}$

(3)

$\begin{array}{lcc} & (521.57) & (0.0061) \\ \text { Educ. 13-15 } & 3059.69 & 0.125 \\ & (516.53) & (0.0057) \\ & & \\ \text { Educ. } \geq 16 & 11954.60 & 0.365 \\ & (603.24) & (0.0051) \\ \text { Age } & 1496.29 & 0.072 \\ & (216.61) & (0.0014) \\ \text { Age }^{2} / 100 & -1602.19 & -0.073 \\ & (267.25) & (0.0017)\end{array}$

$\begin{array}{ll}-8227.00 & -0.208 \\ (6752.42) & (0.0065) \\ & \\ 13097.51 & 0.106 \\ (4968.40) & (0.0053) \\ & \\ 31353.79 & 0.442 \\ (5313.84) & (0.0049) \\ & \\ 5226.86 & 0.073 \\ (3014.62) & (0.0012) \\ & \\ -6592.81 & -0.076 \\ (3170.46) & (0.0014)\end{array}$

Wife:

Educ. 9-11 $\quad-5189.00$

(527.62)

\begin{abstract}
$-0.232$
(0.0084)
\end{abstract}

$-10494.58$

$-0.249$

(7358.55)

$(0.0090)$

Educ. 13-15 $\quad 1147.72$

0.172

(0.0060)

$-480.73$

(4738.68)

0.141

(0.0058)

Educ. $\geq 16 \quad 7407.11$

(639.259)

0.376

17743.35

0.470

(0.0063)

(5495.70)

(0.0055)

Age $\quad 1237.46$

0.036

$-4005.95$

0.044

(0.0015)

(0.0017)

$\mathrm{Age}^{2} \quad-1002.24$

$-0.039$

(2960.81)

$-0.047$

(0.0020)

5668.04

(0.0020)

(272.23)

(3238.41)

0.047

0.022

(0.0002)

Usual weekly

$(0,0002)$

$$
\text { (0.0002) }
$$

$\begin{array}{lc}\text { \#Kids }<6 & -1857.35 \\ & (239.28) \\ & \\ \text { \#Kids6-17 } & -1418.71 \\ & (188.75)\end{array}$

$\mathrm{N}=$

11,884

59,417

44,655

1,891

$80,187 \quad 56,095$

Adj. $R^{2}$

0.250

0.302

0.069

0.448

*Standard errors in parentheses. The estimates describing net income are based on data from the PSID. The estimates of male weekly earnings are least-squares coefficients from regressions using CPS-MORG data. Those describing female weekly earnings are also based on CPS-MORG data and are from a selection model in which the presence of children ages 0-5 and 6-17 identifies the labor-force participation decision. 